\title{
Evaluation of Some Approved Computer Studies Textbooks In Use In Junior Secondary Schools In Ebonyi State Of Nigeria
}

\author{
Umoke C. C. \\ Department of Computer Science \\ Ebonyi State College of Education, Ikwo \\ Dr. Mrs. Nwafor C. E. \\ Department of Science and Computer Education \\ Faculty of Education, Ebonyi State University, Abakaliki
}

\begin{abstract}
This study was designed to evaluate the content adequacy and readability of computer studies textbooks in use in junior secondary schools in Ebonyi state of Nigeria. Eight research questions and two hypotheses guided the study. The sample of the study consisted of three (3) approved computer studies textbooks, 21 junior secondary schools randomly selected from the 3 education zones of Ebonyi State, and 56 computer studies teachers in Ebonyi State. Three (3) instruments were used for data collection: (1) computer studies Textbooks Readability Test (CSTRT) (II) 8-point model by Emerole (2008), an update of quantitative approach to the content evaluation of science textbooks (QACEST) by Nworgu (2001) (III) Teachers' Perception Rating Scale (TPRS). The 8-point model of QACEST was used to answer research questions $1,2,3,4,5$ and 7, research question 6 was answered by using cloze model of readability measurement. The two hypotheses were tested at 0.05 level of significance using chisquare test of goodness of fit. The results of the findings showed that the some approved computer studies textbooks, have adequate contents and learning activities. It also revealed that some of the textbooks has no chapter summaries, the illustrations, chapter summaries, study questions, in some of the textbooks were inadequate. The findings also indicated that the textbooks were culturally, ethnically and gender biased. Based on the findings, conclusions were drawn and was recommended that computer textbooks should be revised periodically to enrich the contents and readability of the textbooks and that a committee of specialists in computer studies should be appointed to selected and possibly approve computer studies textbooks when the need arises, among others.
\end{abstract}

\section{BACKGROUND TO THE STUDY}

Computer studies has become a vital subject in schools as was decided by the Federal Government thereby introducing the 9- year Basic Education Programme so as to attain the Millennium Development Goals (MDGS) by the year 2015. It becomes imperative that the existing curricula for primary and junior secondary schools (JSS) should be reviewed, restructured and re-aligned to fit into a 9-year Basic Education Programme. This assignment was carried out by Nigeria Educational Research and Development Council (NERDC) and after which subject like computer studies was introduced into the programme curriculum with the following objectives:

- To enable the learner to acquire basic computer skills, such as the use of keyboard, mouse and operating system.

- To enable the learner to use the computer to facilitate learning electronically. 
- Develop reasonable level of competence in ICT applications that will engender entrepreneurial skills (NERDC 2007). To fulfill these aims, the use of textbooks becomes absolutely necessary.

Sequel to the above, the modules for computer studies was developed and many computer textbooks were also written. The textbooks enable the teachers teach computer concepts effectively and aim at achieving the general objectives and goals of computer education. The students use it as learning materials to acquire both factual knowledge and skills of scientific enquiry, identifying questions that can be addressed scientifically, doing assignment, planning and carrying out experiments. While the teachers use the textbooks as instructional materials for teaching. Most teachers and students in different parts of the world depend so much on textbooks including those in computer studies as perhaps the only source of information (Baiyelo, 2000). Since textbooks are very important in teaching and learning processes, it needs to be critically evaluated to see whether they are meeting the expected goals of the national policy on education or that of national policy on science and technology. Federal Republic of Nigeria (FRN, 1998,2002).

\section{PURPOSE OF THE STUDY}

The purpose of the study was to evaluate approved computer studies textbooks in use in Junior Secondary Schools in Ebonyi State. Specifically, this study:

1. Determined how the contents of the computer studies textbooks in use in Junior Secondary Schools reflect the content specified in the curriculum for computer studies.

2. Determined the adequacy of the learning activities of each of the computer studies textbooks in use in Junior Secondary Schools.

3. Found out the appropriateness of each of the textbooks chapter summaries to the class level.

4. Determined the adequacy of the study questions in each of the textbooks.

5. Determined the illustration index of each of the computer studies textbooks.

6. Examined the readability levels of the textbooks for each of the classes.

7. Determined the under-represented population index.

8. Examined the teachers' perception of the three computer studies textbooks as useful instructional aid to them.

\section{SCOPE OF THE STUDY}

The study was delimited to the evaluation of the approved computer studies textbooks currently in use in Junior Secondary Schools in Ebonyi state. These textbooks are:

- Computer Made Easy-A Practical Guide for Junior Secondary Schools Book 1-3 by Maria Eze (Textbook A).

- Computer Studies for Beginners Books 1-3 by Oduronke Eyitayo and Adekunle Eyitayo (Textbook B).

- Log on to IT Book 1-3 by Roland Birbal, Michele Taylor (Textbook C).

\section{RESEARCH QUESTIONS}

The following research questions guided the study:

1. How do the contents of computer studies textbooks in use in Junior Secondary Schools reflect the contents specified in the core- curriculum?

2. How adequate are the learning activities of the computer studies textbooks in use in Ebonyi State Junior Secondary Schools?

3. How appropriate are the chapter summaries of the computer studies textbooks in use in Ebonyi State Junior Secondary Schools? 
4. How adequate are the study questions of computer studies textbooks in use in Ebonyi State Junior secondary schools.

5. What is the illustration index of computer studies textbooks in use in Ebonyi State Junior Secondary Schools?

6. What is the readability index of computer studies textbooks in use in Ebonyi State Junior Secondary Schools?

7. What is the under-representation population index of the computer studies textbooks in use in Ebonyi State Junior Secondary Schools?

8. What is the teacher perception index of the computer studies textbooks in use in Ebonyi State Junior Secondary Schools?

\section{HYPOTHESES}

The following null hypotheses were formulated and tested at alpha level of 0.05 .

- H01: The content of the computer studies textbooks in use in the junior secondary schools in Ebonyi state of Nigeria does not significantly deviate from the specifications of the core-curriculum in computer studies.

- H02: The learning activities of each of the approved three computer studies textbooks in use in junior secondary schools in Ebonyi State of Nigeria do not significantly deviate from the specifications of the computer studies core-curriculum.

\section{RESEARCH DESIGN}

The study employed the descriptive evaluation design. Evaluation design is the type of design, which seeks to ascertain, or judge the value of a programme or resources by careful appraisal determined by a pre-stipulated standard (Carter 1989). According to Ali (2006), evaluation design is the type of design that makes value judgement on programmes and projects based on certain pre-determined criteria. This design is useful because the study involved value judgment about computer studies textbooks in use in junior secondary schools in Ebonyi state.

\section{AREA OF THE STUDY}

The area of the study is Ebonyi State of Nigeria. Ebonyi State is located in the south East Zone of Nigeria. It was created in 1996 from both Abia and Enugu State. Specifically, the study covered all the three education zones namely;

Abakaliki, Afikpo and Onueke with 75,82 and 64 (as at 2014) Junior Secondary Schools respectively which summed up to 221 Junior Secondary Schools on the whole. This study was carried out in these zones because no such study had been done there since the creation of the state in 1996.

\section{POPULATION OF THE STUDY}

The population of the study included all the 17 approved computer studies textbooks in use in Ebonyi State, 56 teachers for computer studies in public junior secondary schools $(19,14$ and 23 computer studies teachers for Abakaliki, Afikpo and Onueke education zones respectively) and 70,865 junior secondary schools students (25404,26835 and 18626 for Abakaliki, Afikpo and Onueke education zones respectively) as at 2014, Ebonyi State Universal Basic Education Board record.

\section{Sample and Sampling Techniques}

Three (3) computer studies textbooks (Bk 1-3) out of seventeen (17) approved textbooks for computer studies in Ebonyi State junior secondary schools were simple randomly selected. 


\section{INSTRUMENT FOR DATA COLLECTION}

The instrument used for the data collection is the 8-point quantitative evaluation model for science textbooks. This was developed by Emerole (2008). The model is an update of the 5point quantitative approach for content evaluation of science textbooks (QACEST) developed by Nworgu (2001). It uses the following indices in evaluating science textbooks:

- Topical Coverage Index (TCI)

- Learning Activity Index (LAI)

- Study Question Index (SQl)

- Illustration Index (ILl)

- Chapter Summary Index (CSI)

- Under-Representation Population Index (UPI)

- Readability and Comprehensibility Index (RCI)

- Teacher Perception Rating Index (TPI)

Topical Coverage Index (TCI): Provides an estimate of how far the content of the textbooks covers the prescribed syllabus.

Learning Activity Index (LAI): is an estimate of the degree of which the textbook provides activities that will ensure optimal participation of the learner.

Study Question Index (SQI): Estimates the extent to which the study question in textbooks challenges the learners meaningfully.

Illustration Index (ILI): Is an estimate of the extent to which illustration (diagrams, pictures, charts, tables graphs, equations etc.) contained in the book make for better and more meaningful understanding of the ideas being referred to in the textbook.

Chapter Summary Index (CSI): provides an estimate of the extent to which the chapter summaries promote a more permanent understanding of the content of the book.

Under-Represented Population Index (UPI): Estimate the extent to which the ideas, examples and illustrations that have gender or cultural/ethnic connotation. The textbooks are presented in a neutral or balanced form.

Readability and Comprehensibility Index (RCI): Provides the quantitative estimate of readability and comprehensibility of a textbook. These can be achieved by either applying the Flesch Read Ease Formula (Flesch, 1984) or cloze Test (Graham, 1978: Harrison 1980).

Teacher perception Ration Index (TPI): Estimate the extent of teachers perceptions on how a text book provides instructional support to them.

\section{VALIDATION OF THE INSTRUMENT}

The researcher adopted the 8-point quantitative approach for content evaluation of science textbooks, developed by Emerole (2008) an update of the 5-point quantitative approach for content evaluation of science textbooks (QACEST) developed by Nworgu (2001). The instrument does not need any other validation since the model is already a validated instrument.

\section{RELIABILITY OF THE INSTRUMENT}

The 8-point model for content evaluation of science textbooks, as an update of 5-point (QACEST) model was assessed for reliability using Kendell's coefficient of concordance (W). 
This was necessary because computer studies teachers were used in the evaluation exercise. A reliability coefficient of $0.64,0.66$ and 0.86 were obtained for each of the textbooks using the rating of five teachers

\section{METHOD OF DATA COLLECTION}

Data were collected using the 8-point quantitative approach for content evaluation of science textbooks, using computer studies textbooks. The computer studies teachers of junior secondary schools were trained on how to use the manual of the 8-point quantitative approach for the evaluation of computer studies textbooks to determine the indices of topical-coverage, learning-activities, study-questions, chapter-summaries, illustration index, under represented population index, readability and comprehensibility index and teacher's perception rating index.

\section{METHOD OF DATA ANALYSIS}

The 8-point model quantitative formulae were used to answer the research questions. A standard guideline for calculation and readability level by Harrison (1980) was used to determine students mean readability score in each of the textbooks. Teachers perception rating scale (TPRS), determined teacher perception on how a textbook provides instructional support to them. The hypotheses were tested at 0.05 level of significance using chi-square test of goodness of fit.

\section{Guidelines for Interpreting Cloze Test Scores by Harrison}

\begin{tabular}{|c|c|}
\hline Scores & Interpretation \\
\hline $\begin{array}{l}60 \% \text { and } \\
\text { above }\end{array}$ & $\begin{array}{l}\text { The students' understanding of the text is adequate and they can work on the } \\
\text { book on their own }\end{array}$ \\
\hline $40 \%$ to $59 \%$ & $\begin{array}{l}\text { The students' understanding of the text is adequate enough for the book to be } \\
\text { used with the teacher's assistance. }\end{array}$ \\
\hline Below 40\% & $\begin{array}{l}\text { The students' understanding of the text is inadequate and the use of the book } \\
\text { can lead to frustration. }\end{array}$ \\
\hline
\end{tabular}

\section{RESULT OF THE ANALYSIS}

\section{Research Question 1}

How do the contents of computers studies textbooks in use in Ebonyi State Junior secondary schools reflect the content specified in the core-curriculum? Based on the data collected, the topical coverage index (TCI) was analyzed. The scores of the three computer studies textbooks were calculated and presented in table 1

$\mathrm{TCI}=\frac{T_{t}}{T s}+\frac{S_{t}}{S_{s}} \quad 1 / 2$

Where $\mathrm{T}_{\mathrm{t}}=$ Number of topics covered by the textbook

$\mathrm{T}_{\mathrm{S}}=$ Number of topics in the syllabus

$\mathrm{S}_{\mathrm{t}}=$ Number of sub-topics sufficiently covered by the textbook.

$\mathrm{S}_{\mathrm{s}}=$ Number of sub-topics in the syllabus. 
Table 1: Indices of Topical Coverage (ITC)

\begin{tabular}{|c|c|c|c|c|c|c|c|}
\hline $\mathbf{S} / \mathbf{N}$ & Textbook & CLASS & $\mathbf{T}_{t}$ & $\mathbf{T}_{s}$ & $\mathbf{S}_{\mathbf{t}}$ & $\mathbf{S}_{\mathbf{s}}$ & Index \\
\hline \multirow[t]{4}{*}{1.} & A & JS 1 & 18 & 14 & 33 & 47 & 0.99 \\
\hline & & JS 2 & 9 & 16 & 46 & 48 & 0.76 \\
\hline & & JS 3 & 5 & 8 & 28 & 30 & 0.78 \\
\hline & & Grand mean & & & & & 0.84 \\
\hline \multirow[t]{4}{*}{2.} & B & JS 1 & 11 & 14 & 39 & 47 & 0.81 \\
\hline & & JS 2 & 9 & 16 & 45 & 48 & 0.75 \\
\hline & & JS 3 & 5 & 8 & 27 & 30 & 0.76 \\
\hline & & Grand mean & & & & & 0.77 \\
\hline \multirow[t]{4}{*}{3.} & C & JS 1 & 11 & 14 & 41 & 47 & 0.83 \\
\hline & & JS 2 & 12 & 16 & 43 & 48 & 0.82 \\
\hline & & JS 3 & 8 & 8 & 28 & 30 & 0.97 \\
\hline & & Grand mean & & & & & 0.87 \\
\hline
\end{tabular}

Acceptance range $=0.75$ to 1.00

$\mathrm{Tt}=$ Number of topics covered by the textbook, $\mathrm{Ts}=$ Number of topics in the syllabus, St $=$ Number of sub-topics covered by the textbook Ss - Number of sub-topics in the syllabus.

The results presented in table 1 revealed that all the computer studies textbooks evaluated are within the acceptance range of topical coverage. This implies that they covered the content of the core-computer studies curriculum.

\section{Research Question 2}

How adequate are the learning activities of the computer studies textbooks in use in Ebonyi State Junior secondary schools? The data collected on the learning activities from each of the three computer studies textbooks in use in Ebonyi State Junior secondary schools were analyzed. Based on the results obtained, the learning activity index (LAI) was calculated and presented in Table 2.

$\mathrm{LAI}=\frac{(A-P)}{(A+P)}$

Where, $A=$ Number of sentences requiring the learner to perform some activities.

$\mathrm{P}=$ Number of sentences requiring the learner only to receive information with no other activity. 
Table 2: Learning activity index

\begin{tabular}{llllll}
\hline S/N & Textbook & CLASS & A & P & Index \\
\hline 1. & A & JS 1 & 111 & 12 & 0.80 \\
& & JS 2 & 99 & 17 & 0.71 \\
& & 69 & 11 & 0.73 \\
& JS 3 & & & \\
& & & & 0.75 \\
2. & Grand mean & & & \\
& & JS 1 & 98 & 10 & 0.81 \\
& & JS 2 & 91 & 8 & 0.84 \\
& & JS 3 & 84 & 7 & 0.85 \\
& & & & & \\
3. C & Grand mean & & & 0.83 \\
& & JS 1 & 89 & 9 & 0.82 \\
& JS 2 & 91 & 11 & 0.78 \\
& JS 3 & 84 & 10 & 0.79 \\
& Grand mean & & & 0.80 \\
\hline
\end{tabular}

Acceptance range $=0.50$ to 1.00

The results presented in table 2 revealed the Learning Activity Indices (LAI) for the three computer studies textbooks evaluated. This implies that all the three computer studies textbooks contained leaning activities as specified in the core-computer studies curriculum. Research Question 3

How appropriate are the chapter summaries of the computer studies textbooks in use in Ebonyi State Junior secondary schools? The data collected on chapter summaries was used for the computation of chapter summary index (CSI). The results of the CSI for the three computer studies textbooks evaluated are presented in table 3.

$\mathrm{CSI}=(\mathrm{Js} / \mathrm{Jc}+\mathrm{Ns} / \mathrm{Nc}) / 2$.

Where Js=Number of statements in the summary which represent major points covered in the chapter.

Jc=Number of major points covered in the chapter.

Ns=Number of statements in the summary which represent minor points covered in the chapter.

$\mathrm{Nc}=$ Number of minor points covered in the chapter. 
Table 3: Chapter summaries Indices

\begin{tabular}{llllllll}
\hline S/N & TEXTBOOK & CLASS & $\mathbf{J}_{\mathbf{s}}$ & $\mathbf{J}_{\mathbf{c}}$ & $\mathbf{N}_{\mathbf{s}}$ & $\mathbf{N}_{\mathbf{c}}$ & Index \\
\hline 1. & $\mathrm{~A}$ & JS 1 & No & 38 & No & 56 & No \\
& & summary & & summary & & Index
\end{tabular}

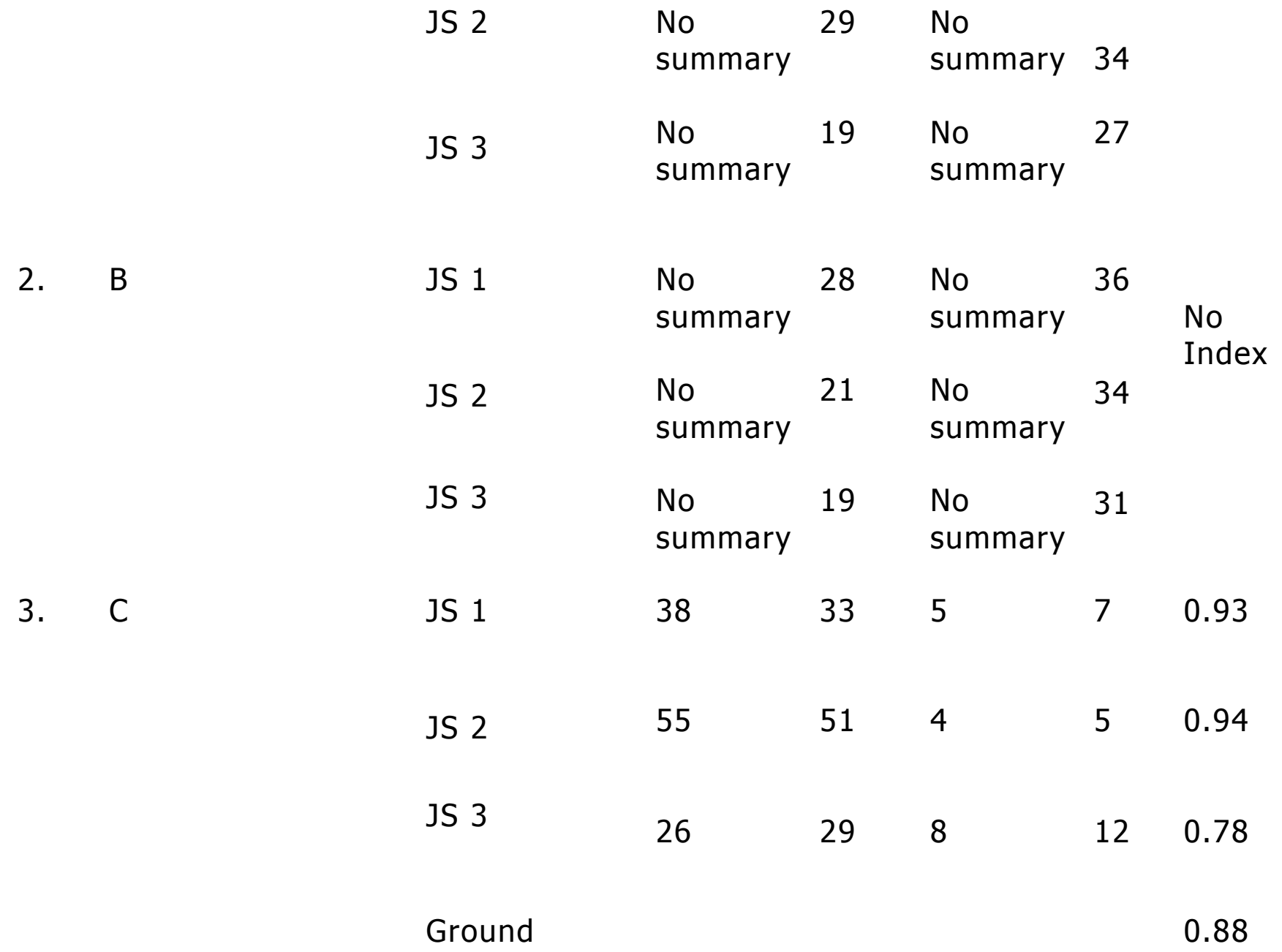

Acceptance range $=0.60$ to 1.00

The table 3 shows the results of the chapter summaries index (CSI) obtained from the data from the three computer studies textbooks in use in Ebonyi State Junior Secondary Schools. The results revealed that one computer studies textbook out of the three textbooks evaluated were within the acceptance range of chapter summary index while the other two had no CSI.

\section{Research Question 4}

How adequate are the study questions of the computer studies textbooks in use in Ebonyi State Junior secondary schools? The data obtained was used for the computation of the StudyQuestions Index (SQI). The computation of the SQI was based on the questions found in each of the five computer studies textbooks evaluated. The results are presented in table 4 below:

SQI $=\frac{(T-R)}{(T+R)}$

Where $\mathrm{T}=$ Number of questions that require students to engaged in real thinking $\mathrm{R}=$ Number of questions that require student to merely recall knowledge. 
Table 4: Study Question index (SQI)

\begin{tabular}{|l|l|l|l|l|l|}
\hline $\mathbf{S} / \mathbf{N}$ & Textbook & CLASS & T & R & Index \\
\hline 1. & A & JS 1 & 49 & 6 & 0.78 \\
& & JS 2 & 20 & 3 & 0.74 \\
& & JS 3 & 13 & 3 & 0.63
\end{tabular}

$\begin{array}{llllll}\text { 2. B } & \text { Ground } & & & 0.72 \\ & \text { JS } 1 & 63 & 19 & 0.54 \\ & \text { JS 2 } & 49 & 13 & 0.58 \\ & \text { JS 3 } & 96 & 12 & 0.78 \\ & & & & \\ \text { 3. Ground } & & & 0.63 \\ & \text { mean } & & & \\ & \text { JS 1 } & 136 & 29 & 0.65 \\ & \text { JS 2 } & 106 & 24 & 0.63 \\ & \text { JS 3 } & 89 & 19 & 0.65 \\ & \text { Ground } & & & 0.64 \\ & \text { mean } & & & & \end{array}$

Acceptance range $=-0.25$ to +1.00

Table 4 shows the study questions index for the three computer studies textbooks (SQI) in use in Ebonyi State Junior Secondary Schools. The results presented in table 4 reveals that all the three computer studies textbooks evaluated are within the acceptance range of study questions index. This implies that all the textbooks evaluated contained adequate study questions.

\section{Research questions 5}

What are the illustrations index of computer studies textbooks in use in Ebonyi State Junior secondary schools? The data obtained on illustrations found in each of the three computer studies textbooks evaluated were used for the computation of the illustrations index (ILI). The results are presented in table 5.

$\mathrm{ILI}=\frac{\left(L_{a}-L_{b}\right)}{\left(L_{a}+L_{b}\right)}$

Where $L_{a}=$ Number of illustrations requiring the learner to perform some activities.

$\mathrm{L}_{b}=$ Number of illustrations requiring the learner only to view. 
Table 5: Illustration Index (ILI)

\begin{tabular}{llllll}
\hline $\mathbf{S} / \mathbf{N}$ & Textbook & CLASS & $\mathbf{L}_{\mathbf{a}}$ & $\mathbf{L}_{\mathbf{b}}$ & Index \\
\hline 1. & $\mathrm{~A}$ & JS 1 & 32 & 72 & -0.38 \\
& & JS 2 & 29 & 61 & -0.36 \\
& & JS 3 & 26 & 51 & -0.32 \\
& & Ground mean & & & -0.35 \\
2. B & \multirow{2}{*}{ B } & JS 1 & 31 & 71 & -0.39 \\
& & JS 2 & 33 & 69 & -0.35 \\
& & JS 3 & 28 & 61 & -0.37 \\
& \multirow{2}{*}{ C } & Ground mean & & & -0.37 \\
& & JS 1 & 34 & 79 & -0.39 \\
& & JS 2 & 33 & 71 & -0.37 \\
& JS 3 & 30 & 68 & -0.39 \\
& Ground mean & & & -0.38 \\
\hline
\end{tabular}

Acceptance range $=-0.50$ to 0.00

Table 5 above indicates the mean scores of the illustrations index (ILI) in each of the three computer studies textbooks evaluated. The results presented in table 5 reveals that the three computer studies textbooks evaluated are within the acceptance range of illustration index (ILI) of -0.50 to 0.00 . This implies that all the textbooks evaluated contained illustrations.

\section{Research Question 6}

What is the readability index of the computer studies textbooks in use in Ebonyi State Junior secondary schools? The data used in answering this research question were obtained from the "Close Test of Readability of Computer Studies Textbooks" (CTRCST), the mean readability scores of the three Computer Studies Textbooks evaluation were computed and presented in the table 6.

Table 6 below shows the readability scores for all the three computer studies textbooks in use in Ebonyi State Junior Secondary Schools. The results presented in Table 6 reveals that the readability scores of the evaluated textbooks are within the acceptance range of readability. 


\section{Table 6: Readability Index}

\begin{tabular}{|c|c|c|c|c|}
\hline $\mathbf{S / N}$ & Textbook & CLASS & $\begin{array}{l}\text { Mean } \\
\text { Readability } \\
\text { score }\end{array}$ & Decision \\
\hline 1. & $A$ & $\begin{array}{l}\text { JS } 1 \\
\text { JS } 2 \\
\text { JS } 3 \\
\text { Ground mean }\end{array}$ & $\begin{array}{l}60.1 \% \\
61.2 \% \\
61.1 \% \\
60.8 \%\end{array}$ & $\begin{array}{l}\text { Very Readable } \\
\text { Very Readable } \\
\text { Very Readable }\end{array}$ \\
\hline 2. & B & $\begin{array}{l}\text { JS } 1 \\
\text { JS } 2 \\
\text { JS } 3 \\
\text { Ground mean }\end{array}$ & $\begin{array}{l}61.5 \% \\
63.1 \% \\
62.1 \% \\
62.2 \%\end{array}$ & $\begin{array}{l}\text { Very Readable } \\
\text { Very Readable } \\
\text { Very Readable }\end{array}$ \\
\hline 3. & $\mathrm{C}$ & $\begin{array}{l}\text { JS } 1 \\
\text { JS } 2 \\
\text { JS } 3 \\
\text { Ground mean }\end{array}$ & $\begin{array}{l}56.2 \% \\
55.1 \% \\
58.1 \% \\
56.5 \%\end{array}$ & $\begin{array}{l}\text { Very Readable } \\
\text { Very Readable } \\
\text { Very Readable }\end{array}$ \\
\hline
\end{tabular}

Acceptance range $=40 \%$ and above

\section{Research Question 7}

What is the Under-Representation Population Index of the computer studies textbooks in use in Ebonyi State junior secondary schools? The data obtained from the three computer studies textbooks evaluated were used to answer research question 7 . The results of the data analysis are presented on table 7.

$\mathrm{UPI}=(\mathrm{G}-\mathrm{B}) /(\mathrm{G}+\mathrm{B})$

Where $G=$ Number of illustrations, examples, gender and ethnic connoted statements that are neutral. biased.

$B=$ Number of illustrations, examples, gender, and ethnic connoted statements that are 
Table 7: Under-Represented populations index (UPI)

\begin{tabular}{|c|c|c|c|c|c|c|}
\hline $\mathbf{S} / \mathbf{N}$ & TEXTBOOK & CLASS & $\mathbf{G}$ & B & Index & Decision \\
\hline \multirow[t]{6}{*}{1.} & $A$ & $\begin{array}{l}\text { JS } 1 \\
\text { JS } 2\end{array}$ & 90 & 18 & 0.67 & Accepted \\
\hline & & & 75 & 4 & 0.89 & Accepted \\
\hline & & JS 3 & & & & \\
\hline & & & 27 & 4 & 0.74 & Accepted \\
\hline & & Ground mean & & & & \\
\hline & & & & & 0.77 & \\
\hline \multirow[t]{5}{*}{2.} & B & $\begin{array}{l}\text { JS } 1 \\
\text { JS } 2\end{array}$ & 121 & 30 & 0.60 & Accepted \\
\hline & & JS 3 & 100 & 13 & 0.77 & Accepted \\
\hline & & & 30 & 15 & 0.33 & Accepted \\
\hline & & Ground mean & & & & \\
\hline & & & & & 0.57 & \\
\hline \multirow[t]{4}{*}{3.} & C & $\begin{array}{l}\text { JS } 1 \\
\text { JS } 2\end{array}$ & 64 & 8 & 0.78 & Accepted \\
\hline & & JS 3 & 54 & 15 & 0.57 & Accepted \\
\hline & & Ground mean & 62 & 10 & 0.72 & Accepted \\
\hline & & & & & 0.69 & \\
\hline
\end{tabular}

Acceptance range $=-1.00$ to +1.00

Table 7 shows the under-represented population index for each of the computer studies textbooks evaluated. The results presented in table 7 reveals that all the computer studies textbooks evaluated are within the acceptance range of under-represented populations index (UPI) of -1.00 to +1.00 .

The under-represented population index (UPI) of the three computer studies textbooks evaluated ranged from 0.33 to 0.89 .

\section{Research Question 8}

What is the teacher perception index of the computer Studies textbooks in use in Ebonyi State junior secondary schools? The data used in answering this research question 8 were obtained from teachers' perception rating scale (TPRS), an instrument development by Emereole and Rammiki (2004) and adopted for the study. The results obtained are presented on table 8. 
Table 8: Mean rating of Teachers perception index of the computer Studies textbooks.

A

\begin{tabular}{|l|l|l|l|l|l|l|l|l|l|}
\hline S/N & JS1 & JS 2 & JS 3 & JS 1 & JS 2 & JS 3 & JS 1 & JS 2 & JS 3 \\
\hline 1 & 3.07 & 3.03 & 3.10 & 3.07 & 4.00 & 3.93 & 3.97 & 4.00 & 3.83 \\
\hline 2 & 3.03 & 3.07 & 3.07 & 3.03 & 3.53 & 3.50 & 2.7 & 2.77 & 2.63 \\
\hline 3 & 3.03 & 3.07 & 3.07 & 3.03 & 2.67 & 2.73 & 3.6 & 3.67 & 3.57 \\
\hline 4 & 2.33 & 2.37 & 2.37 & 2.33 & 2.67 & 2.63 & 3.67 & 3.70 & 3.60 \\
\hline 5 & 3.5 & 3.53 & 3.53 & 3.5 & 3.60 & 3.60 & 3.2 & 3.23 & 3.13 \\
\hline 6 & 3.27 & 3.30 & 3.30 & 3.27 & 3.73 & 3.77 & 3.57 & 3.63 & 3.53 \\
\hline 7 & 3.23 & 3.27 & 3.27 & 3.23 & 3.43 & 3.47 & 3.37 & 3.40 & 3.33 \\
\hline 8 & 3.57 & 3.60 & 3.60 & 3.57 & 3.30 & 3.20 & 2.43 & 2.47 & 2.40 \\
\hline 9 & 2.73 & 2.77 & 2.73 & 2.73 & 3.73 & 3.77 & 3.53 & 3.57 & 3.47 \\
\hline 10 & 3.37 & 3.33 & 3.43 & 3.37 & 3.07 & 3.03 & 4.17 & 4.23 & 4.13 \\
\hline 11 & 2.17 & 2.13 & 2.20 & 2.17 & 2.97 & 2.97 & 3.07 & 3.13 & 3.03 \\
\hline 12 & 3.23 & 3.27 & 3.30 & 3.23 & 3.40 & 3.40 & 3.1 & 3.13 & 3.03 \\
\hline 13 & 3.77 & 3.73 & 3.83 & 3.77 & 3.67 & 3.57 & 3.47 & 3.53 & 3.43 \\
\hline 14 & 2.73 & 2.70 & 2.80 & 2.73 & 4.00 & 4.00 & 3.67 & 3.73 & 3.60 \\
\hline 15 & 3.17 & 3.10 & 3.27 & 3.17 & 3.47 & 3.47 & 3.37 & 3.40 & 3.33 \\
\hline 16 & 2.67 & 2.63 & 2.70 & 2.67 & 2.67 & 2.67 & 4.2 & 4.23 & 4.13 \\
\hline 17 & 3.33 & 3.37 & 3.37 & 3.33 & 3.57 & 3.47 & 3.2 & 3.23 & 3.17 \\
\hline 18 & 1.6 & 1.57 & 1.53 & 1.6 & 1.53 & 1.57 & 3.43 & 3.47 & 3.40 \\
\hline 19 & 3.5 & 3.53 & 3.53 & 3.5 & 3.53 & 3.50 & 4.00 & 4.03 & 3.97 \\
\hline 20 & 3.77 & 3.80 & 3.87 & 3.77 & 2.83 & 2.83 & 3.8 & 3.83 & 3.73 \\
\hline & 3.05 & 3.06 & 3.09 & 3.31 & 3.27 & 3.25 & 3.48 & 3.52 & 3.42 \\
\hline
\end{tabular}

Grand mean $=3.07$

3.28

\section{B}

Acceptance range $=3.00$ to 5.00 
Table 9: Chi-square table on the significance of Deviation of the three computer studies textbooks contents from the specification of computer studies core-curriculum.

\begin{tabular}{|c|c|c|c|c|c|c|c|c|c|c|}
\hline$S / N$ & Textbook & CLASS & $T_{t}$ & $\mathrm{~T}_{s}$ & $S_{t}$ & $\mathbf{S}_{\mathrm{s}}$ & $\mathrm{X}^{2} \mathrm{cal}$ & Alpha & $X^{2}$ crit & Decision \\
\hline 1. & A & JS 1 & $\begin{array}{l}18 \\
(10.9)\end{array}$ & $\begin{array}{l}14 \\
(14.1)\end{array}$ & $\begin{array}{l}33 \\
(40.7)\end{array}$ & $\begin{array}{l}47 \\
(46.3)\end{array}$ & & & & \\
\hline
\end{tabular}

\begin{tabular}{|c|c|c|c|c|c|c|c|c|c|c|}
\hline & & JS 2 & $\begin{array}{l}9 \\
(11.5)\end{array}$ & $\begin{array}{l}16 \\
(14.96)\end{array}$ & $\begin{array}{l}46 \\
(43.3)\end{array}$ & $\begin{array}{l}48 \\
(49.2)\end{array}$ & & & & \\
\hline & & JS 3 & $\begin{array}{l}5 \\
(6.9)\end{array}$ & $\begin{array}{l}8 \\
(8.9)\end{array}$ & $\begin{array}{l}28 \\
(25.8)\end{array}$ & $\begin{array}{l}30 \\
(29.4)\end{array}$ & & & & \\
\hline \multirow[t]{4}{*}{2.} & B & JS 1 & $\begin{array}{l}11 \\
(10.8)\end{array}$ & $\begin{array}{l}14 \\
(13.95)\end{array}$ & $\begin{array}{l}39 \\
(40.4)\end{array}$ & $\begin{array}{l}47 \\
(45.9)\end{array}$ & & & & \\
\hline & & JS 2 & $\begin{array}{l}9 \\
(11.4)\end{array}$ & $\begin{array}{l}16 \\
(14.8)\end{array}$ & $\begin{array}{l}45 \\
(42.9)\end{array}$ & $\begin{array}{l}48 \\
(48.8)\end{array}$ & & & & \\
\hline & & & & & & & 9.65 & 0.05 & 36.42 & Accept \\
\hline & & JS 3 & $\begin{array}{l}5 \\
(6.8)\end{array}$ & $\begin{array}{l}8 \\
(8.8)\end{array}$ & $\begin{array}{l}27 \\
(25.5)\end{array}$ & $\begin{array}{l}30 \\
(28.9)\end{array}$ & & & & \\
\hline \multirow[t]{3}{*}{3.} & C & JS 1 & $\begin{array}{l}11 \\
(10.96)\end{array}$ & $\begin{array}{l}14 \\
(14.2)\end{array}$ & $\begin{array}{l}41 \\
(41.1)\end{array}$ & $\begin{array}{l}47 \\
(46.7)\end{array}$ & & & & \\
\hline & & JS 2 & $\begin{array}{l}12 \\
(11.5)\end{array}$ & $\begin{array}{l}16 \\
(14.96)\end{array}$ & $\begin{array}{l}43 \\
(43.3)\end{array}$ & $\begin{array}{l}48 \\
(49.2)\end{array}$ & & & & \\
\hline & & JS 3 & $\begin{array}{l}8 \\
(7.2)\end{array}$ & $\begin{array}{l}8 \\
(9.3)\end{array}$ & $\begin{array}{l}28 \\
(26.9)\end{array}$ & $\begin{array}{l}30 \\
(30.6)\end{array}$ & & & & \\
\hline
\end{tabular}

Table 9 shows the chi-square calculated value of 9.65 and the critical value of 36.42 at alpha level of 0.05 of significant. From the results on this table and based on decision rule, the researcher accepts the null hypothesis. This means that the contents of the three computer studies textbooks evaluated do not significantly deviate from the specifications of the computer studies core curriculum.

Ho2: The learning activities of each of the approved three computer studies textbooks in use in Junior secondary schools in Ebonyi State of Nigeria do not significantly deviate from the specifications of the computer studies core-curriculum.

The learning activities in each of the five computer textbooks evaluated in this study were matched with the learning activities specified in the computer core-curriculum. The frequencies of $A=N$ umber of sentences requiring the learner to perform some activities and $\mathrm{P}=$ Number of sentences requiring the learner only to receive information with no other activity, were subjected to chi-square test of goodness of fit. The summary of the result is presented on table 10. 
Table 10: Chi-square table on significance of correspondence of the learning activities in the three computer studies textbooks with the specification of the computer core-curriculum.

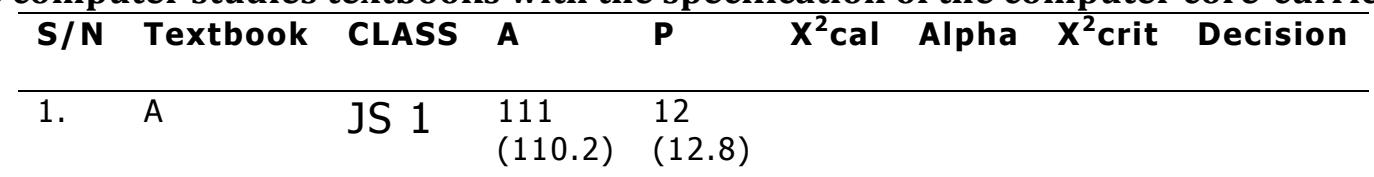

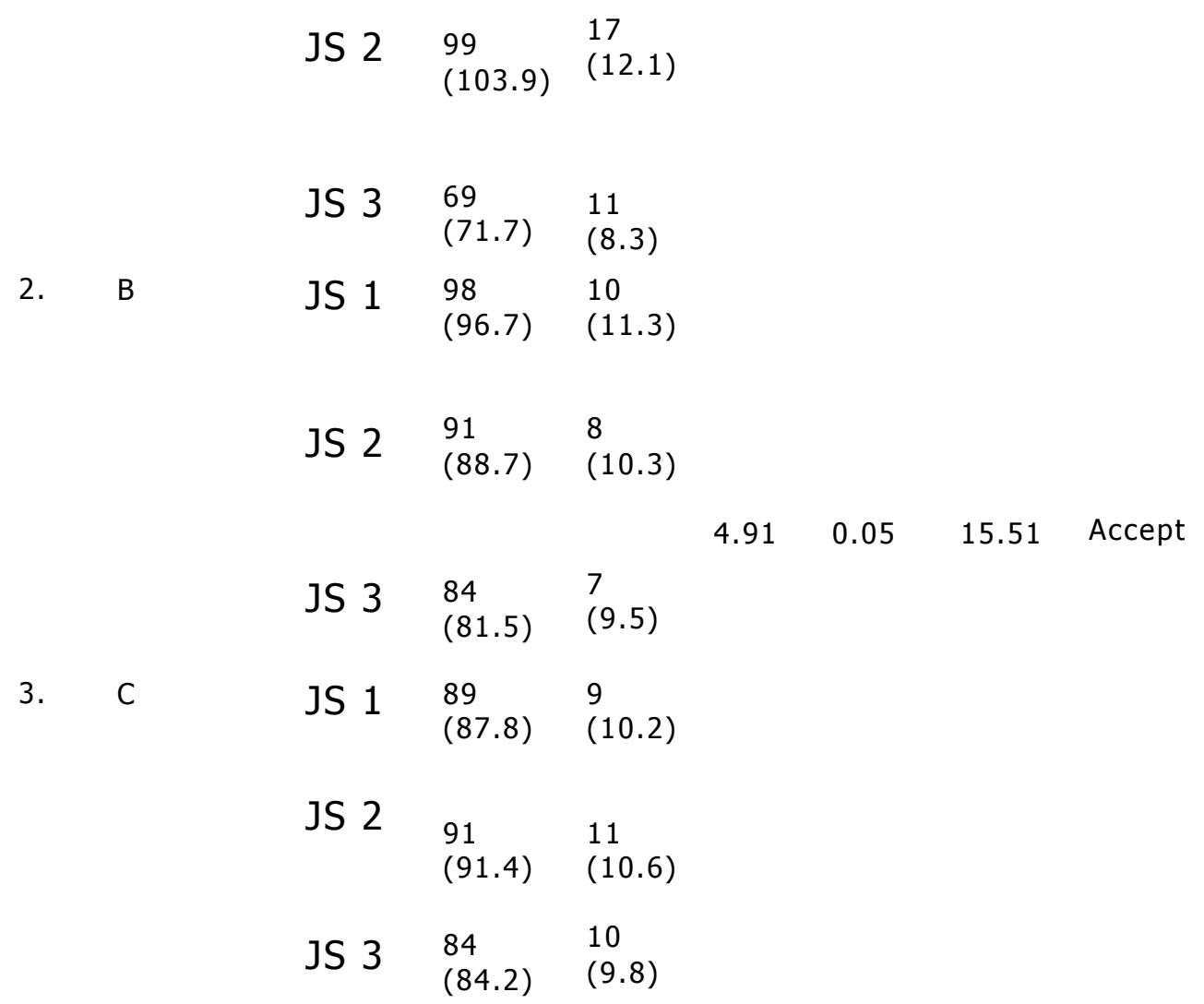

Table 10 shows the chi-square calculated value of 4.91 and the critical value of 15.51 at alpha level of 0.05 of significant. From the results on this table and based on decision rule, the researcher accepts the null hypothesis and concludes that the learning activities in the three computer studies textbooks evaluated do not deviate significantly from the specifications of the computer studies core-curriculum.

The major findings of the study based on the eight research question that guided the study are:

1. Correspondence of the content of the computer studies textbooks evaluated with the specification of the computer studies core-curriculum.

2. Adequacy of the learning activities of the computer studies text-books in use in Junior Secondary Schools in Ebonyi State.

3. Appropriateness of the chapter summaries of the computer studies textbooks in use in Junior secondary schools in Ebonyi State.

4. Adequacy of the study questions in the computer studies textbooks in use in Junior secondary schools in Ebonyi State.

5. Appropriateness of the illustration in the computer studies textbooks in use in junior secondary schools in Ebonyi State.

6. The under-representation population index in the three computer studies textbooks evaluated. 
7. The teachers' perception of the computer studies textbooks in use in junior secondary schools in Ebonyi State.

Correspondence of the content of the computer studies textbook evaluated with the specification of the computer studies core-curriculum.

The result obtained indicate that the topical coverage index (TCI) or index of topical coverage for the three computer studies textbooks were as follows, Textbook A had 0.99, 0.76 and 0.78 for JS 1, JS 2 and JS 3 respectively Textbook B had $0.81,0.75$ and 0.76 for the class levels respectively and Textbook $C$ had $0.83,0.82$ and 0.97 for JS 1, JS 2 and JS 3 respectively. The index of the topical coverage of the three computer studies textbooks are high, it could be that the authors consulted the core-curriculum before writing the textbooks. The results of the finding are not in conformity with some earlier studies. The result of the findings in this study agreed with the work of Emereoke and Rammiki (2008), who evaluated the content of all the physics textbooks used in Botswana secondary schools and reported that the index of topical coverage (ITC) were high.

The results of this study indicate that the contents of the three computer studies textbooks evaluated and which are in use in junior secondary schools in Ebonyi state correspond with the specification of computer studies core-curriculum. The researcher therefore accepted the first null hypothesis.

The Adequate of the learning activities of the computer Studies textbooks in use in junior secondary schools in Ebonyi State

The results obtained showed that the mean score for each of the three textbooks were as follows: Textbooks A had $0.80,0.71$ and 0.73 for JS I, JS 2 and JS 3 respectively, Textbook B had $0.81,0.84$ and 0.85 for the class levels respectively and Textbooks $C$ had $0.82,0.78$ and 0.79 for JS 1, JS 2 and JS 3 respectively.The result indicates that the learning activities indices in these three computer studies textbooks are adequate. This result of the finding agreed with the study carried out by Omiko (2011), his study revealed that the learning activities in the chemistry textbooks evaluated in Ebonyi state were adequate. The researcher therefore accepts the second null hypothesis.

Appropriateness of the Chapter Summaries of the Computer studies textbooks in use in Junior Secondary Schools in Ebonyi State.

The results of data analysis obtained for the study indicate that one computer studies textbooks out of the three textbooks evaluated had chapter summaries index of 0.93, 0.94 and 0.78 for JS 1 JS 2 and JS 3 respectively using Textbook C while Textbooks A and B had no chapter summaries index because there had no chapter summaries.

This shows that the one computer studies textbook in use in junior secondary schools in Ebonyi State have chapter summaries.

The finding of the study agreed with the study of Omiko (2011), who evaluated the content and readability of some recommended chemistry textbooks in Ebonyi state secondary schools. The study reported that the chemistry textbooks cover the syllabus appropriately and also contain adequate chapter summaries. 
Adequacy of the Study Questions in the three Computer Studies Textbooks in use in Junior Secondary Schools in Ebonyi State

The data collected and the results obtained showed that the three approved computer studies textbooks in use in junior secondary schools in Ebonyi State had the following mean scores on study questions index (SQI).

Textbook A had $0.78,0.74$ and 0.63 for JS 1, JS 2 and JS 3 respectively, Textbook B had 0.65 , 0.58 and 0.78 for the class levels respectively and Textbook $C$ had $0.65,0.65,0.63$ and 0.65 for JS 1, JS 2 and JS 3 respectively. These results indicate that two computer studies textbooks used in this study had average study questions index (SQI). It also implies that these textbooks contained some study questions. This is in line with Baiyelo (2000), who evaluated the content and readability of some selected physics textbooks.

Appropriateness of the Illustrations Index in the three Computer Studies Textbooks Evaluated.

From the data collected on illustration index in each of the three computer studies textbooks, it was found that the textbooks had the following mean scores. Textbook A had $-0.38,-0.36$ and 0.32 for JS 1 JS 2 and JS 3 respectively, Textbook B had $-0.39,-0.35$ and -0.37 for the class levels respectively and Textbook C had $-0.39,-0.37$ and -0.39 for JS 1 , JS 2 and JS 3 respectively.

The results showed that the illustration index in all the three computer studies textbooks is low. The results of the findings agree with Omiko (2011) who evaluated the content and readability of recommended chemistry textbooks in use in Ebonyi State secondary schools. He reported that the chemistry textbooks have low illustrations index and that the illustrations in the textbooks are not adequate. He recommended the revision of these textbooks to include illustrations.

Readability of the Computer Studies Textbooks in use in Junior Secondary School in Ebonyi State

The data collected and the results obtained on readability showed that the three computer studies textbooks evaluated had the following mean readability scores: Textbook A had $60.1 \%$, $61.2 \%$ and $61.1 \%$ for JS 1, JS 2 and JS 3 respectively, Textbook B had $61.5 \%, 63.1 \%$ and $62.1 \%$ for the class levels respectively and Textbook C had 56.2\%, 55.1\% and 58.1\% for JS 1, JS 2 and JS 3 respectively.

The result indicate that all the three computer studies textbooks evaluated are readable, the findings are in agreement with Omiko (2011) whose work showed that all the chemistry textbooks he evaluated are readable.

The Under-representation Population Index (UPI) in the three Computer Studies Textbooks Evaluated

The result of findings showed that the mean scores of all the textbooks were as follows: Textbook A had $0.67,0.89$ and 0.74 for JS 1, JS 2 and JS 3 respectively, Textbook B had 0.60 , 0.77 and 0.33 for the class levels respectively and Textbook $\mathrm{C}$ had $0.78,0.57$ and 0.72 for JS 1 , JS 2 and JS 3 respectively. 
This indicates that these computer studies textbooks are culturally, ethnically and gender biased. They contain some terms and illustrations that are not acceptable to both males and females. These terms and illustrations may discourage the genders that are not favoured and this may make them become disadvantaged in the subject.

The Teachers' Perception of the three Computer Studies Textbooks in use in Junior Secondary Schools in Ebonyi State

The summary of the results was presented on table 8; it revealed the mean rating scores of all the three computer studies textbooks based on the class levels of JS 1, JS 2 and JS 3 respectively. The questionnaire items which the teachers rated were drawn from the computer studies core-curriculum. It covered the following areas:

1. Content coverage: The textbook coverage of topics and sub-topics specified in the syllabus

2. Presentation of content: How the content is presented to direct learners' attentions to the main ideas.

3. Illustrations: The alternative ways of presenting or explaining information as in diagrams, graphs, pictures, tables, charts etc. to reach learners of different abilities.

4. Problems solving activities: Analyzing and manipulating data, drawing conclusions and making predictions.

5. Experimental and investigative activity: Doing scientific experiments and planning investigations in order to develop the skills.

6. Study questions: Questions and exercises at the end of chapters or sub-topics meant to promote development of thinking skills and problem solving strategies.

7. Worked examples: Questions and their solutions in the textbooks to demonstrate problems-solving and applications of knowledge.

8. Readability: The ease with which learners can read and understand the textbook.

The teachers' perception of the three computer studies textbooks as their instructional aid was presented on table 8 the grand mean rating scores for the three textbooks were as follows: Textbook A had 3.07, Textbook B had 3.28 and Textbook C 3.47. Since these results were above 3.00 , it implies that the teachers agreed that these textbooks provide instructional support to them.

\section{CONCLUSIONS}

Based on the results of the findings of the study, the following conclusions were drawn:

1. The contents of all the computer studies textbooks evaluated appropriately reflected the contents specified in the computer studies core-curriculum.

2. All the three computer studies textbooks in use in Junior Secondary Schools in Ebonyi State contain learning activities.

3. One out of three computer studies textbooks in use in Junior Secondary Schools in Ebonyi State contain chapter summaries. The researcher concludes that the chapter summaries of the computer studies textbooks in use in Junior Secondary Schools in Ebonyi State were appropriate.

4. All the computer studies textbooks in use in Junior Secondary Schools in Ebonyi State have both average and high study questions index (SQI).

5. The three computer studies textbooks have low illustration index.

6. Based on the Harrison's (1980) interpretation of cloze readability of textbooks, it was found that all the three computer studies textbooks in use in Junior Secondary Schools in Ebonyi State are readable. 
7. The three computer studies textbooks have high under-representation population index. The researchers concludes that these textbooks were culturally, socially, ethnically and gender biased.

8. The teachers' perception of the computer studies textbooks in use in Junior Secondary Schools in Ebonyi State was adequate. This was reflected on the mean scores of all the computer studies textbooks evaluated. Based on this the researcher concluded that the teachers affirmed that the textbooks are useful to them in their instructional delivery.

\section{RECOMMENDATIONS}

Based on the findings and conclusions of this study, the researcher made the following recommendations:

1. Scientific knowledge and discoveries are increasing everyday, especially in the area of ICT applications, it is necessary that all the computer studies textbooks in use in junior secondary schools in Ebonyi State should be revised periodically. This would help to enrich the content and readability of the textbooks. Those computer studies textbooks whose readability and contents are high should be recommended for the Junior Secondary Schools.

2. A committee of specialists/experts should be appointed, to select and recommend computer studies textbooks. Such specialists/experts should include computer/ education specialists, computer teachers, curriculum planners, computer studies textbook authors, science teachers, expert representative from State Universal Basic Education Board. The selection and recommendation of any computer studies textbook should be based on acceptable yardstick (standard) laid down by the expert.

3. Students and teachers are advised to use many of the approved computer studies textbooks in both their studies and lessons. The students should consult the computer studies core-curriculum before deciding on the computer studies textbook to use. Those computers studies textbooks that are readable and has high content validity should be selected.

4. Computer studies textbook authors and publishers should consult computer studies core-curriculum when writing and publishing their books. This will help them to choose topics, performance objectives, contents and learning activities from the specified corecurriculum. This would help the authors to achieve high topical coverage, learning activities, study questions and chapter summaries indices.

5. Computer professional and Educational bodies, Government, donor agencies, private school proprietors should help to organize conferences, seminar and workshops for computer studies teachers on the recent ICT applications and the best way of impacting the knowledge into the students.

6. The State Ministries of Education should organize workshops and conferences for the textbook authors and publishers on how to organize and use the core-curriculum in writing high quality textbooks.

7. One textbook should not be recommended. It is always better to use more than one textbook in any particular subject. What one textbook did not cover may be covered or treated better by others.

8. The computer studies textbook authors should incorporate recent windows (operating system) and application software where necessary so as to always get the students updated.

\section{References}

Ali, M. (2006). Government of Ebonyi State of Nigeria, Ministry of Education, Abakaliki. List of Approved and Recommended Textbooks for the senior secondary schools and Technical colleges in Ebonyi State from September 2006-July 2009. 
Baiyelo, J.O (2000). An Evaluation of the Adequacy of physics textbooks used in Lagos State secondary Schools. ISEDJO. Issues in Education Journal 1 (1) 1-20.

Carter, V.G. (1989). ADictionary of Education. New York Harper Row.

Emereole, H. U., and Rammiki, R. (2008). Content evaluation of Physics textbooks used in Botswana secondary schools. Mosenodi, Journal of Bostswana Education Research Association. 12(1\&2)69-81.

Federal Ministry of Education Bulletin. Abuja. National Policy on Education (2004)

Harrison, C. (1980) Readability in the classroom. Cambridge: Cambridge University press.

Nigeria Educational Research and Development Council (2007).

Nworgu, B.G. (2001) A 5-point quantitative model for the evaluation of the content of science textbooks. Journal of the science Teachers Association of Nigeria. 36 (1\&2) 10-16.

Omiko, A. (2011). Evaluation of Chemistry textbooks in use in Secondary Schools in Ebonyi State of Nigeria. Unpublished Ph.D Thesis, presented to Department of Science Education, Faculty of Education, Ebonyi State University Abakaliki. 